\title{
Faktor yang Berhubungan dengan Skor Maternal-Fetal Attachment Pada Ibu Hamil
}

\author{
Wahidah Sukriani ${ }^{1}$, Endang Koni Suryaningsih ${ }^{2}$ \\ ${ }^{1}$ Jurusan Kebidanan, Politeknik Kesehatan Kemenkes Palangka Raya, Indonesia \\ ${ }^{2}$ Prodi DIII Kebidanan Universitas 'Aisyiyah Yogyakarta \\ Email:wahidahsukriani@gmail.com
}

\begin{abstract}
Factors Associated with Maternal-Fetal Attachment Scores in pregnant women. Maternal-Fetal Attachment (MFA) is a bond between mother and fetus during pregnancy. MFA plays an important role in maternal and fetal health and affects mothers' decisions in healthy behaviors during pregnancy. Several factors predicted to affect the MFA is the age of pregnancy, maternal age, gravida, pregnancy status, marital status, occupation, income and education of the mother. This study aims to determine the factors associated with maternal-fetal attachment scores in pregnant women in the Panarung Puskesmas Palangka Raya. This was an observational analytic study with a cross-sectional design. A sample in this research is a pregnant woman who does a pregnancy examination at Puskesmas Panarung Kota Palangka Raya. The instrument used in this research is the Indonesian version of prenatal attachment inventory (PAI). Data analysis was done by logistic regression. The results of statistical tests showed a significant relationship between gestational age with MFA score $(\mathrm{p}<0.05)$. Mothers with a gestational age $>28$ weeks had a better MFA score because the mother already felt the presence of her fetus.
\end{abstract}

Keywords: Gestasional Age, Maternal Fetal Attachment.

\begin{abstract}
Abstrak: Faktor yang Berhubungan dengan Skor Maternal-Fetal Attachment pada ibu hamil. Maternal Fetal Attachment (MFA) merupakan ikatan antara ibu dan janin dalam masa kehamilan. MFA berperan penting dalam kesehatan ibu dan janin dan berpengaruh pada keputusan ibu dalam berperilaku sehat selama kehamilan. Beberapa faktor yang diprediksi berhubungan terhadap skor MFA yaitu usia kehamilan, usia ibu, gravida, status kehamilan, status pernikahan, pekerjaan, pendapatan dan pendidikan ibu. Penelitian ini bertujuan untuk mengetahui faktor yang berhubungan dengan skor maternal fetal attachment pada ibu hamil di Puskesmas Panarung Kota Palangkaraya. Penelitian ini merupakan penelitian analitik observasional dengan rancangan cross- sectional. Sampel pada penelitian ini adalah ibu hamil yang melakukan pemeriksaan kehamilan di Puskesmas Panarung Kota Palangka Raya. Instrumen yang digunakan pada penelitian ini adalah lembar isian dan kuesioner "Indonesian version of Prenatal Attachment Inventory (PAI)". Analisis data dilakukan dengan regresi logistik. Hasil uji statistik menunjukkan adanya hubungan signifikan antara usia kehamilan dengan skor MFA $(p<0,05)$. Ibu dengan usia kehamilan $>28$ minggu
\end{abstract}

Kata kunci: Maternal Fetal Attachment, Usia Kehamilan

Pembangunan kesehatan merupakan bagian dari pembangunan nasional yang dilakukan oleh pemerintah setiap negara. Indikator derajat kesehatan suatu negara dapat dinilai melalui angka kematian diantaranya adalah angka kematian neonatal (AKN). Angka Kematian Neonatal di Indonesia berdasarkan laporan SDKI tahun 2012 adalah 19/1000 kelahiran hidup. Kematian neonatal sebagian besar diakibatkan oleh berat lahir rendah, asfiksia dan infeksi (BkkbN et al., 2012). Luaran neonatal yang kurang baik seperti berat lahir rendah disebabkan oleh berbagai faktor yang salah satunya berhubungan dengan maternal fetal attachment (MFA) dan perilaku kesehatan ibu selama kehamilan (Alhusen et al., 2012).

MFA merupakan ikatan antara ibu dan janin dalam masa kehamilan. Hal ini dapat dilihat dari keterlibatan ibu dalam menunjukkan kasih sayangnya, melakukan perawatan serta komitmen untuk menjaga janinnya (Walsh, 2010). MFA berperan penting dalam kesehatan ibu dan janin dan berpengaruh pada keputusan ibu dalam berperilaku sehat selama kehamilan (Simpson and Rholes, 2010). Ibu yang mempunyai skor MFA tinggi memiliki perilaku yang lebih baik terhadap perawatan dirinya dan kehamilannya 
dibandingkan ibu dengan skor rendah (Alhusen et al., 2012)

Berdasarkan salah satu studi literatur, beberapa faktor yang diprediksi berpengaruh terhadap MFA yaitu usia kehamilan, dukungan sosial, pemeriksaan kehamilan, kecemasan, kepercayaan diri, usia ibu, paritas, status pernikahan, pendapatan dan pendidikan ibu (Yarcheski A et al., 2009). Penelitian ini bertujuan untuk mengetahui faktor yang berhubungan dengan skor maternal fetal attachment pada ibu hamil di Puskesmas Panarung Kota Palangka Raya.

\section{METODE}

Penelitian ini merupakan penelitian analitik observasional dengan rancangan cross-sectional. Penelitian ini dilakukan di Puskesmas Panarung Kota Palangka Raya pada bulan Mei-Juli 2017.

Populasi pada penelitian ini adalah seluruh ibu hamil di Puskesmas Panarung. yang memeriksakan kehamilannya di Puskesmas Panarung pada bulan Mei- Juli 2017. Perhitungan jumlah sampel yang diperlukan menggunakan rumus Lemeshow sehingga jumah sampel yang diperlukan adalah $97 \mathrm{ibu}$ hamil. Pengambilan sampel akan dilakukan dengan teknik consecutive sampling yaitu semua ibu hamil yang datang melakukan pemeriksaan kehamilan di Puskesmas Panarung yang memenuhi kriteria inklusi akan dijadikan sampel penelitian.

Kriteria inklusi pada penelitian ini adalah ibu hamil yang berdomisili di wilayah Puskesmas Panarung dan tidak memiliki penyakit penyerta berat selama kehamilan ini. Kriteria eksklusi adalah Responden yang tidak bersedia berpartisipasi dalam penelitian.

Instrument yang digunakan untuk megukur MFA pada penelitian ini adalah Prenatal Attachment Inventory (PAI) versi Bahasa Indonesia yang telah diterjemahkan, diadaptasikan oleh peneliti (Suryaningsih, 2015) dan telah mendapatkan persetujuan dari peneliti asli PAI (Muller, 1993). PAI versi Bahasa Indonesia terdiri dari 21 item merujuk pada 4 skala likert dengan kisaran skor antara 21 hingga 84 . Semakin tinggi skor, merepresentasikan semakin tinggi level MFA (Muller, 1993). Hasil pilot studi dari PAI versi Bahasa Indonesia menjamin kualitas hasil adaptasi dengan construct validity ( $\mathrm{p}$ $<$.05) melalui pendekatan contrasted group dan Cronbach' Alpha .937 (Suryaningsih, 2015). logistic.

\section{HASIL}

Hasil analisis univariat dari variabel skor MFA, usia ibu, gravida, usia kehamilan, pendidikan ibu, pekerjaan ibu, status pernikahan, status kehamilan dan pendapatan keluarga dapat dilihat pada tabel distribusi frekuensi dibawah ini :

\begin{tabular}{|c|c|c|}
\hline Variabel & $\mathbf{n}$ & $\%$ \\
\hline \multicolumn{3}{|l|}{ Skor MFA } \\
\hline Tinggi & 52 & 53,6 \\
\hline Rendah & 45 & 46,4 \\
\hline \multicolumn{3}{|l|}{ Usia Ibu } \\
\hline$<35$ Tahun & 84 & 86,6 \\
\hline$\geq 35$ Tahun & 13 & 13,4 \\
\hline \multicolumn{3}{|l|}{ Gravida } \\
\hline Primigravida & 39 & 40,2 \\
\hline Multigravida & 58 & 59,8 \\
\hline \multicolumn{3}{|l|}{ Usia Kehamilan } \\
\hline$<28$ minggu & 41 & 42,3 \\
\hline$\geq 28$ minggu & 56 & 57,7 \\
\hline \multicolumn{3}{|l|}{ Pendidikan Ibu } \\
\hline Pendidikan Rendah & 29 & 29.9 \\
\hline Pendidikan Menengah & 68 & 70.1 \\
\hline \multicolumn{3}{|l|}{ Pekerjaan Ibu } \\
\hline Tidak Bekerja & 74 & 76,3 \\
\hline Bekerja & 26 & 23,7 \\
\hline \multicolumn{3}{|l|}{ Status Pernikahan } \\
\hline Belum/Tidak Menikah & 3 & 3,1 \\
\hline Menikah & 94 & 96,9 \\
\hline \multicolumn{3}{|l|}{ Status Kehamilan } \\
\hline Tidak Terencana & 8 & 8,2 \\
\hline Terencana & 89 & 91,8 \\
\hline \multicolumn{3}{|l|}{ Pendapatan keluarga } \\
\hline$<\mathrm{UMR}$ & 45 & 46,4 \\
\hline$\geq \mathrm{UMR}$ & 52 & 53,6 \\
\hline
\end{tabular}

Berdasarkan tabel diatas diketahui bahwa sebagian besar ibu hamil memiliki skor MFA dalam kategori tinggi yaitu 53,6\%. Pada perhitungan skor MFA ini, dikatakan termasuk dalam kategori tinggi jika skor ibu berada diatas rata-rata nilai skor dari keseluruhan sampel, yang mana pada penelitian ini nilai rata-ratanya adalah $61,86,6 \%$ ibu hamil berada dalam usia $<35$ tahun, lebih banyak ibu hamil merupakan ibu dengan multigravida yaitu $59,8 \%$, usia kehamilan ibu lebih banyak pada usia $\geq 28$ minggu kehamilan atau berada pada trimester III kehamilan, pendidikan ibu hamil sebagian besar adalah pendidikan tinggi yaitu $70,1 \%$. Pendidikan tinggi yang dimaksud adalah sekolah menengah atas atau 
sederajat dan perguruan tinggi, sebagian besar ibu hamil tidak bekerja atau merupakan ibu rumah tangga yaitu sebesar $76,3 \%$, terdapat ibu hamil dengan status belum/tidak menikah meskipun jumlahnya sedikit yaitu $3,1 \%$, sebagian besar kehamilan ibu adalah kehamilan terencana yaitu sebesar 91,8\%, lebih banyak ibu hamil dengan pendapatan keluarga $\geq$ UMR ( $\geq$ Rp. 2.300.000) yaitu sebanyak 53,6\%.

Tabel 2. Hubungan usia ibu, gravida, usia kehamilan, pendidikan, pekerjaan, status pernikahan, status kehamilan dan pendapatan keluarga dengan Skor MFA pada ibu hamil di Puskesmas Panarung Kota Palangka Raya Tahun 2017

\begin{tabular}{|c|c|c|c|c|c|c|c|}
\hline \multirow[t]{3}{*}{ Variabel } & \multicolumn{4}{|c|}{ Skor MFA } & \multirow{3}{*}{$\begin{array}{c}\text { Nilai } \\
p\end{array}$} & \multirow[t]{3}{*}{ OR } & \multirow[t]{3}{*}{ CI } \\
\hline & \multicolumn{2}{|c|}{ Rendah } & \multicolumn{2}{|c|}{ Tinggi } & & & \\
\hline & $\mathbf{n}$ & $\%$ & $\mathbf{n}$ & $\%$ & & & \\
\hline \multicolumn{8}{|l|}{ Usia Ibu } \\
\hline$<35$ Tahun & 39 & 40,2 & 45 & 46,3 & $0,985^{*}$ & 0.989 & $0,306-3,192$ \\
\hline$\geq 35$ Tahun & 6 & 6,2 & 7 & 7,3 & & & \\
\hline \multicolumn{8}{|l|}{ Gravida } \\
\hline Primigravida & 18 & 18,6 & 21 & 21,6 & $0,969 *$ & 1,016 & $0,450-2,293$ \\
\hline Multigravida & 27 & 27,8 & 31 & 32,0 & & & \\
\hline \multicolumn{8}{|l|}{ Usia Kehamilan } \\
\hline$<28$ minggu & 27 & 27,8 & 14 & 14,4 & $0,001 *$ & 0,246 & $0,104-0,578$ \\
\hline$\geq 28 \mathrm{minggu}$ & 18 & 18,6 & 38 & 39,2 & & & \\
\hline \multicolumn{8}{|l|}{ Pendidikan Ibu } \\
\hline Pendidikan Rendah & 12 & 12,3 & 17 & 17,5 & $0,518 *$ & 1,336 & $0,555-3,216$ \\
\hline Pendidikan Menengah & 33 & 34,1 & 35 & 36,1 & & & \\
\hline \multicolumn{8}{|l|}{ Pekerjaan Ibu } \\
\hline Tidak Bekerja & 38 & 39,2 & 36 & 37,1 & $0,079 *$ & 2,413 & $0,889-6,547$ \\
\hline Bekerja & 7 & 7,3 & 16 & 16,4 & & & \\
\hline \multicolumn{8}{|l|}{ Status Pernikahan } \\
\hline Belum/Tidak Menikah & 1 & 1,0 & 2 & 2,1 & $0,555^{* *}$ & 1,760 & $0,154-20,080$ \\
\hline Menikah & 44 & 45,4 & 50 & 51,5 & & & \\
\hline \multicolumn{8}{|c|}{ Perencanaan Kehamilan } \\
\hline Tidak Terencana & 3 & 3,1 & 5 & 5,2 & $0.442 * *$ & 0,671 & $0,151-2,981$ \\
\hline Terencana & 42 & 43,3 & 47 & 48,4 & & & \\
\hline \multicolumn{8}{|l|}{ Pendapatan keluarga } \\
\hline <UMR & 23 & 23,7 & 22 & 22,7 & $0,386^{*}$ & 0,701 & $0,314-1,565$ \\
\hline$\geq \mathrm{UMR}$ & 22 & 22,7 & 30 & 30,9 & & & \\
\hline
\end{tabular}

*uji chi square, ** uji fisher exact

Analisis multivariat dilakukan untuk mengetahui variable paling dominan yang berhubungan dengan skor MFA. Variabel yang diikutkan pada analisis multivariate adalah variable denga nilai $\mathrm{p}<0,25$ yaitu usia kehamilan dan pekerjaan ibu. Hasil analisis multivariate dapat dilihat pada tabel di bawah ini:

Tabel 3. Hasil analisis multivariat faktor yang berhubungan dengan skor MFA

\begin{tabular}{llccc} 
& Variabel & Sig & Exp $(\mathbf{B})$ & CI \\
\hline \multirow{2}{*}{ Step $1^{\text {a }}$} & Usia Kehamilan & 0,00 & 5,031 & $2,005-12,625$ \\
& Pekerjaan & 0,27 & 0,287 & $0,094-0,869$ \\
\hline
\end{tabular}

Berdasarkan tabel di atas diketahui bahwa usia kehamilan dan pekerjaan berhubungan dengan skor MFA. Ibu dengan usia kehamilan $\geq$ 28 minggu memiliki skor MFA 5,031 kali lebih tinggi dibanding ibu dengan usia kehamilan $<28$ minggu dan pada ibu yang bekerja hanya memiliki skor MFA 0,287 kali lebih tinggi dibandingkan ibu yang tidak bekerja. 


\section{PEMBAHASAN}

\section{Hubungan Usia ibu dengan skor MFA}

Hasil analisis univariat menunjukkan responden pada penelitian ini sebagian besar berusia <35 tahun. yang merupakan usia reproduksi sehat sehingga merupakan usia aman untuk proses kehamilan. Pada ibu usia $<35$ tahun maupun usia $\geq 35$ tahun pada penelitian ini samasama memiliki lebih banyak skor MFA yang tinggi dibanding yang rendah, sehingga berdasarkan hasil uji statistik diperoleh hasil tidak ada hubungan yang signifikan antara usia ibu dengan skor MFA.

Hasil ini tidak sejalan dengan penelitian Ustunsoz et al (2010) yang menemukan bahwa MFA akan menurun seiring dengan meningkatnya usia ibu hamil. Wanita usia lebih dari 35 tahun menunjukkan skor MFA yang lebih rendah dibandingkan ibu usia 20-an. Attachment dari ibu ke janin pada ibu dengan usia lebih tua akan menurun. Hal ini diduga dapat disebabkan ibu sudah memiliki anak sebelumnya dan ibu memiliki lebih banyak tanggung jawab dalam hidupnya. Bertambahnya jumlah anak dalam keluarga dengan meningkatnya usia ibu membuat adaptasi terhadap kehamilan menjadi lebih sulit sehingga dapat menurunkan level skor MFA. (Baghdari. N. et al., 2016)

Namun, hasil uji statistik pada penelitian ini sejalan dengan penelitian sebelumnya oleh Torshizi \& Sharifzadeh (2013) di Iran dan Abasi et al (2012) yang menyatakan tidak ada hubungan antara MFA dengan usia ibu. Selain itu, Yarcheski et al (2009) pada meta analisisnya menyatakan bahwa usia ibu memiliki efek rendah dalam MFA. Tidak adanya hubungan dapat dikarenakan faktor lain diluar usia ibu yang dapat meningkatkan skor MFA seperti usia kehamilan, dan faktor dukungan social yang terbukti memiliki hubungan yang kuat terhadap skor MFA.

\section{Hubungan Gravida dengan Skor MFA}

Hasil analisis univariat menunjukkan bahwa 59,8\% responden penelitian merupakan ibu multigravida dan hasil penelitian pada uji bivariat menunjukkan bahwa baik pada ibu primigravida dan multigravida sama-sama memiliki lebih banyak skor MFA tinggi sehingga hasil uji statistik menunjukkan tidak ada hubungan yang signifikan antara gravida dan skor MFA ( $p>0,05)$.

Hasil penelitian yang sama diperoleh pada penelitian Hassan (2017) bahwa skor MFA pada ibu primigravida cenderung tinggi, karena secara psikologis ibu ingin memiliki peran baru yang belum pernah dirasakan sebelumnya sehingga akan lebih sibuk dengan pikiran dan emosi tentang kehamilan dan janin yang tumbuh yang akan menyebabkan tingginya skor MFA(Noha Mohamed Mahmoud Hassan and Hassan, 2017).

Penelitian lain oleh Nicols et al (2007) menunjukkan hasil yang berbeda bahwa ibu multigravida memiliki skor MFA yang lebih rendah dibandingkan dengan primigravida. Hal ini dimungkinkan karena ibu kurang fokus terhadap kehamilannya saat ini karena lebih memperhatikan anak yang lainnya (Nichols. et al., 2007)

Tidak adanya hubungan antara gravida dengan skor MFA pada penelitian ini tidak sejalan dengan hasil penelitian Hassan et al (2017) yang menyatakan ada korelasi negative antara gravida dan skor MFA. Meningkatnya gravida ibu akan menurunkan level skor MFA(Hassan et al, 2017). Hasil meta analisis oleh Yarcheski et al (2009) menyatakan bahwa banyaknya kehamilan memiliki efek yang rendah terhadap attachment ibu dan janin (Yarcheski et al, 2009). Hasil yang berbeda pada penelitian ini dapat dikarenakan adanya factor lain yang berhubungan dengan tingginya skor MFA pada ibu multigravida pada penelitian ini seperti sosial budaya, serta dukungan sosial yang pada penelitian ini tidak teramati dikarenakan keterbatasan peneliti namun berdasarkan kajian pustaka memiliki pengaruh kuat terhadap skor MFA.

\section{Hubungan Usia Kehamilan dengan Skor MFA}

Responden pada penelitian ini sebagian besar merupakan ibu hamil dengan usia kehamilan $\geq 28$ minggu yaitu $57,7 \%$. Ibu dengan usia kehamilan <28 minggu lebih banyak yang memiliki skor MFA rendah sedangkan ibu dengan usia kehamilan $\geq 28$ minggu lebih banyak memiliki skor MFA tinggi. Hasil uji statistik menunjukkan ada hubungan yang signifikan antara skor MFA dengan usia kehamilan ibu ( $\mathrm{p}$ $0,05)$.

Hasil penelitian ini sesuai dengan penelitian terdahulu yang menyatakan bahwa semakinbesar usia kehamilan, ibu akan lebih intensif dalam melakukan MFA sehingga skor MFA akan lebih tinggi (Sandbrooks and Adamson-Macedo, 2004). Hasil meta analisis terhadap hubungan usia kehamilan dengan MFA juga menunjukan hasil yang sama,bahwa usia kehamilan memiliki efek menengah hingga tinggi dengan tingkat korelasi yang kuat terhadap MFA, sehingga usia kehamilan disebutkan sebagai predictor paling kuat dari MFA (Yarcheski et al, 2009). Penelitian lain oleh Walsh et al (2010) juga 
mendapatkan hasil yang sama bahwa ibu pada usia kehamilan lebih tinggi (23 dan 33 minggu) mempuyai skor MFA lebih tinggi disbanding ibu dengan usia kehamilan 13 minggu. Hasil penelitian ini konsisten dengan hasil penelitian terdahulu (Muller, 1994; Suryaningsih 2015; Vedova et al, 2008). Menurut para peneliti, dengan bertambahnya usia kehamilan maka gerakan janin akan semakin terasa dan sensasi tersebut semakin menguatkan ikatan batin antara ibu dan janin. Hal ini dikuatkan oleh penelitian senior dari Rubin (1985). Menurut Rubin, selama kehamilan Trimester I attachment dari ibu ke janin belum terjadi dikarenakan ibu belum merasakan hadirnya janin. Pada trimester II kehamilan, gerakan bayi dan perubahan hormone meningkatkan penerimaan atau kesadaran ibu akan kehamilannya dan pada trimester III meningkat dan bertumbuh secara drastis (Rubin, 1985).

\section{Hubungan Pendidikan Ibu dengan Skor MFA}

Ibu yang memiliki pendidikan rendah maupun pendidikan tinggi lebih banyak yang memiliki skor MFA tinggi. Hasil uji statistik menunjukkan tidak hubungan yang signifikan antara pendidikan ibu dengan skor MFA $(p>0,05)$

Hasil penelitian ini sejalan dengan penelitian Abasi et al (2012) di Iran dan penelitian Hassan \& Hassan (2017) yang juga memperoleh hasil bahwa level pendidikan ibu tidak berhubungan dengan skor MFA Pendidikan yang lebih tinggi semestinya membuka peluang bagi ibu untuk mencari dan memanfaatkan informasi kesehatan lebih banyak. Ibu dengan pendidikan tinggi diharapkan dapat mengembangkan keterampilan yang lebih baik untuk mendorong perkembangan anak-anak mereka (Noha Mohamed Mahmoud Hassan and Hassan, 2017).

Tidak adanya hubungan antara pendidikan ibu dengan skor MFA dapat dikarenakan sudah terbukanya akses informasi mengenai kehamilan dan kesehatan yang dapat diperoleh ibu melalui berbagai media. Seiring perkembangan jaman, informasi dan pengetahuan sudah dapat diakses oleh siapa saja dan dimana saja sehingga memungkinkan adanya pengetahuan yang sama pada ibu dengan tingkat pendidikan rendah maupun tinggi.

\section{Hubungan Pekerjaan Ibu dengan Skor MFA}

Ibu yang tidak bekerja lebih banyak memiliki skor MFA yang rendah sedangkan pada responden yang bekerja sebagian besar memiliki skor MFA tinggi. Hasil uji bivariat menunjukkan tidak ada hubungan yang signifikan antara pekerjaan dan skor MFA ( $p>0,05)$, namun hasil uji multivariat menunjukkan adanya hubungan meskipun nilai OR nya rendah

Penelitian Hassan \& Hassan (2017) mendapatkan hasil bahwa pekerjaan ibu tidak berhubungan dengan skor MFA. Hal ini dapat dikarenakan pekerjaan tidak lagi menjadi penghalang dalam menjalani kehamilan. Pada ibu pekerja seringkali informasi yang didapatkan mengenai kesehatan menjadi lebih luas dan lebih banyak dibandingkan pada ibu yang tidak bekerja.

Penelitian lain Brook-Gun et all (2010) menemukan fakta bahwa pada ibu yang bekerja penuh waktu didapati skor yang lebih rendah pada beberapa aspek perkembangan kognitif anak. Sejatinya, masa transisi menjadi seorang ibu merupakan proses yang menantang yang menuntut cara baru dalam mengatur rutinitas harian.

\section{Hubungan Status Pernikahan Ibu dengan Skor MFA}

Pada penelitian ini Responden yang belum/tidak menikah maupun pada yang sudah menikah lebih banyak yang memiliki skor MFA tinggi sehingga hasil uji statistik menunjukkan tidak ada hubungan yang signifikan antara status pernikahan dan skor MFA ( $p>0,05)$.

Hasil penelitian ini tidak sejalan dengan penelitian yang dilakukan oleh Jang et al (2015) yang menyatakan bahwa wanita hamil yang belum menikah merupakan populasi yang rentan mengalami kesulitan dalam melaksanakan MFA. Hal ini dikarenakan asumsi bahwa wanita hamil yang tidak menikah mempunyai kehidupan seksual yang negatif sehingga dukungan keluarga dan masyarakat terhadap kehamilannya kurang. Selain itu, rendahnya kepercayaan diri ibu untuk kehamilannya dan kemungkinan adanya kebenciannya terhadap kehamilannya memungkinkan ibu mengalami kesulitan melakukan MFA (Jang et al., 2015)

Penelitian lain oleh Moussa et al (2012) di Mesir menyatakan bahwasanya bukanlah status pernikahan ataupun lama pernikahan yang memberi pengaruh kepada bonding ibu ke janin namun hubungan antara suami istri lah yang memberi pengaruh signifikan. Hal ini dikarenakan sesungguhnya dukungan sosial yang mempengaruhi attachment.

Dukungan sosial tidak hanya didapatkan dari suami, namun juga dari keluarga dan masyarakat, sehingga pada penelitian ini pada ibu dengan status belum/tidak menikah dapat 
memiliki skor MFA tinggi dimungkinkan oleh karena terpenuhinya dukungan sosial dari keluarga maupun masyarakat.

\section{Hubungan Perencanaan kehamilan dengan Skor MFA}

Pada penelitian ini diperoleh hasil responden yang kehamilannya terencana maupun tidak terencana lebih banyak yang memiliki skor MFA tinggi dan uji statistik menunjukkan tidak ada hubungan yang signifikan antara status kehamilan dan skor MFA ( $p>0,05)$.

Hasil yang sama diperoleh pada penelitian Damato (2004) yang menyatakan bahwa status kehamilan dalam hal ini perencanaan kehamilan bukanlah faktor prediktif dari MFA. Namun, hasil ini bertolak belakang dengan penelitian Abasi et al (2012) di Iran yang menyatakan pada kehamilan yang direncanakan memiliki skor MFA yang lebih tinggi dibandingkan pada kehamilan yang tidak direncanakan, dikarenakan pada kehamilan tidak terencana kemungkinan merupakan kehamilan dengan bayi yang tidak diinginkan.

Pada penelitian ini pada ibu dengan kehamilan yang tidak terencana juga memiliki skor MFA tinggi karena dipengaruhi oleh faktor lain terutama dukungan social baik dari suami, keluarga dan masyarakat yang terbukti mempunyai pengaruh besar terhadap MFA.

\section{Hubungan Pendapatan Keluarga dengan Skor MFA}

Responden dengan pendapatan keluarga $<$ UMR lebih banyak yang memiliki skor MFA rendah, sedangkan pada responden dengan pendapatan keluarga $\geq$ UMR lebih banyak yang memiliki skor MFA tinggi. Namun, hasil uji statistik menunjukkan tidak ada hubungan yang signifikan antara pendapatan keluarga dan skor MFA ( $p>0,05)$.

Sosial ekonomi yang tidak adekuat, dapat menyebabkan tidak efektifnya hubungan ibu dengan janinnya karena ibu akan lebih fokus memikirkan keterbatasan ekonominya (Hassan \&Hassan, 2017). Hasil penelitian ini sejalan dengan penelitian terdahulu oleh Lindgren (2001) dan Abasi et al (2012) yang juga memperoleh hasil yang sama bahwa tidak ada hubungan pendapatan dengan skor MFA. Namun, berdasarkan meta analisis yang dilakukan oleh Yarcheski et al (2009) dari 9 penelitian diketahui terdapat hubungan antara pendapatan dengan MFA meskipun tingkat hubungannya lemah.

\section{SIMPULAN}

Faktor usia kehamilan berhubungan dengan dengan skor MFA. Semakin besar usia kehamilan akan meningkatkan skor MFA.

\section{SARAN}

Diperlukan pengenalan MFA kepada ibu hamil oleh tenaga kesehatan melalui konseling saat pemeriksaan kehamilan dan dapat dimasukkan dalam materi kelas ibu hamil sehingga diharapkan dapat meningkatkan ikatan atau bonding antara ibu dan janin

\section{DAFTAR PUSTAKA}

Abasi, E., Tahmasebi, H., Zafari, M., Takami, GN. 2012. Assesment on effective Factors of Maternal-Fetal Attachment in Pregnant Woman. Life Science Journal 9, 68-75.

Alhusen, J. L., Gross, D., Haya, M. J., Woods, A. B. N. \& Sharps, P. W. 2012. The Influence Of Maternal-Fetal Attachment And Health Practices On Neonatal Outcomes In LowIncome, Urban Women. Res Nurs Health, 35, 112-120.

Baghdari. N., Sadeghi. E., K. M. \& Azmoude. E. 2016. The Effects Of PregnancyAdaptation Training On Maternal-Fetal Attachment And Adaptation In Pregnant Women With A History Of Baby Loss. Nurs Midwifery Stud, 5, 5-8.
Jang, S. H., Kim, I. J. \& Lee, S. H. 2015. Relationship Between Social Support And Maternal Fetalattachment Among Unmarried Pregnant Women In Korea: The Mediating Effects Of Self-Esteem Advanced Science And Technology Letters, 104, 24-28.

Lindgren, K. 2001. Relationship Among Maternal-Fetal Atatchment, Prenatal. Research In Nursing \& Health, 24, 203-217

Moussa, S et al. 2012. Correlates of Antenatal Bonding: An Egyptian Study. Egyptian Journal of Physciatry 33:126-134.

Muller, M.E. 1993. Development of the prenatal attachment inventory. Western Journal of 
Nursing Research, 15(2), 199-215. Doi: $10.1177 / 01939459930150025$.

Muller, M.E. 1994. A questionnaire to measure mother-to-infant attachment. Journal of Nursing Measurement, 2(2), 129-141.

Nichols Mr., Roux Gm. \& Harris Nr. 2007. Primigravid And Multigravid Women: Prenatal Perspectives. Journal Of Perinatal Education, 16, 21-32.

Noha Mohamed Mahmoud Hassan \& Hassan, F. M. A. E. 2017. Predictors Of Maternal Fetal Attachment Among Pregnant Women Journal Of Nursing And Health Science, 6, 95-106.

Rubin, R. 1985. Maternal Task in Pregnancy. Maternal-Child Nursing Journal 4(3), 14353

Sandbrooks SP \& Adamson-Macedo EN 2004. Maternal-Fetal Attachment: Searching For A New Definition Neuro Endocrinology Letters, 25 Suppl 1, 169-182.

Simpson, J. A. \& Rholes, W. S. 2010. Attachment And Relationships: Milestones And Future Directions. Journal Of Social And Personal Relationships 27, 173-180.

Suryaningsih, E.K. 2015. Indonesian Version of Prenatal Attachment Inventory. Department of Nurse-Midwifery. National Taipei University of Nursing and Health Sciences. Thesis.
Thompson, R. A. 2008. Early Attachment And Later Development: Familiar Questions, New Answers. In J. Cassidy \& P. R. Shaver (Eds.), Handbook Of Attachment (2nd Ed.) New York, Guilford Press.

Torshizi, M.\& Sharifzadeh, G. 2013. Maternalfetal attachment and associated Factors in Pregnant Women referred to Birjand Health Centers (2012). Journal of Birjand University of Medical Sciences 20(3), 27987.

Ustunsoz A, Guvenc G, Akyuz A, \& Oflaz F. 2010. Comparison of maternal and parental-fetal attachment in Turkish couples. Midwifery 26 (2), el-9

Walsh, J. 2010. Definitions Matter: If MaternalFetal Relationships Are Not Attachment, What Are They? Archives Of Womens's Maternal Health, 13, 449-451.

Yarcheski A, Mahon Ne, Yarcheski Tj, Hanks Mm \& Cannella B1 2009. A Meta-Analytic Study Of Predictors Of Maternal-Fetal Attachment. International Journal Of Nursing Studies, 46, 708-715.

Zevalkink, J., Walvaren, J. M. R. \& Bradley, R. H. 1999. The Quality Of Children Home Environment And Attachment Security In Indonesia. The Journal of Genetic Psychology, 169, 72-91. 